\title{
Percutaneous Management of Postoperative Bile Leaks with an Ethylene Vinyl Alcohol Copolymer (Onyx)
}

\section{Perkutane Therapie postoperativer Galleleckagen mittels eines Ethylen-Vinylalkohol-Kopolymers (Onyx)}

Authors

Affiliations
W. Uller ${ }^{1}$, R. Müller-Wille ${ }^{1}$, M. Loss ${ }^{2}$, S. Hammer ${ }^{1}$, S. Schleder ${ }^{1}$, H. Goessmann ${ }^{1}$, P. Wiggermann ${ }^{1}$, C. Stroszczynski ${ }^{1}$, W. A Wohlgemuth ${ }^{1}$

Department of Radiology, University Medical Center Regensburg

Department of Surgery, University Medical Center Regensburg

\section{Key words}

bile ducts

interventional procedures

percutaneous

- PTC

PTBD

- biliary leakage

eingereicht 6.4 .2013

akzeptiert 21.6.2013

\section{Bibliography}

DoI http://dx.doi.org/

10.1055/s-0033-1350153

Published online: 16.7.2013

Fortschr Röntgenstr 2013; 185:

1182-1187 (c) Georg Thieme

Verlag KG Stuttgart · New York · ISSN 1438-9029

\section{Correspondence}

Frau Dr. Wibke Uller

Institut für Röntgendiagnostik, Universitätsklinikum

Regensburg

Franz Josef Strauss Allee 11

93053 Regensburg

Germany

Tel.: ++49/0941/9447431

Fax: ++49/0941/9447481

wibke.uller@ukr.de

\section{Zusammenfassung}

$\nabla$

Ziel: Die Therapie postoperativer Galleleckagen ist sehr anspruchsvoll, insbesondere wenn sich das Galleleck an der Resektionsfläche der Leber befindet und eine endoskopische Therapie nicht erfolgreich ist. Eine perkutane Behandlung ist möglich, aber meist mit langen Drainagenverweildauern und Therapieversagen vergesellschaftet. Diese Studie evaluiert den selektiven Verschluss von Gallengängen mit einem Ethylen-Vinylalkohol-Kopolymer (Onyx) als Therapieoption bei Patienten mit postoperativem Galleleck.

Material und Methoden: Zwischen Januar und September 2012 wurde bei 5 konsekutiven Patienten mit persistierenden postoperativen Galleleckagen perkutan transhepatisch Onyx appliziert. Das prozedurale Vorgehen, Komplikationen sowie technischer Erfolg wurden evaluiert.

Ergebnisse: Die persistierenden Galleleckagen befanden sich an der Absetzung des Ductus cysticus nach Cholezystektomie ( $\mathrm{n}=2$ ), an der Resektionsfläche (nach erweiterter Leberresektion $n=2$ ) und an der Leberoberfläche nach chirurgischer Exploration und perihepatischem Abszess $(n=1)$. Die Therapie mit alleiniger Drainage der Galleflüssigkeit (endoskopisch oder perkutan) versagte bei allen Patienten und erneute offene chirurgische Revisionen wurden als zu invasiv gewertet. Die Biliome wurden bei allen Patienten vor Onyxapplikation nach extern drainiert. Zum Verschluss des Gallelecks wurde Onyx durch einen Mikrokatheter in ein zuvor platziertes Coilnest appliziert um eine Dislokation des Onyxs mechanisch zu verhindern. Alle Galleleckagen waren initial sofort verschlossen. In der 2. Woche nach Onyxverschluss zeigten 2 Patienten ein wiederauftretendes, kleines, klinisch asymptomatisches Galleleck. In der 4. Woche nach Onyxapplikation waren alle Leckagen verschlossen. Es traten keine Komplikationen auf.

\section{Abstract \\ $\nabla$}

Purpose: The management of postoperative bile leakage is challenging especially if the leak rises from the cut surface of the liver and endoscopic treatment fails. Percutaneous transhepatic treatment of bile leaks with biliary drainage is accepted but often requires long-term placement of the drains and is associated with treatment failures. This series evaluates selective embolization of bile ducts with an ethylene vinyl alcohol copolymer (Onyx) in patients with postoperative bile leaks as an alternative treatment option.

Materials and Methods: Between January and September 2012, five consecutive patients with persistent postoperative bile leaks underwent percutaneous transhepatic Onyx application and were analyzed regarding procedural management, complications and success rates.

Results: The persistent bile leaks were situated at the cystic stump (after cholecystectomy, $n=2$ ), at the cut surface of the liver (after extended liver resection, $n=2$ ) and at the surface of the liver after surgical exploration and perihepatic abscess $(n=1)$. Bile drainage alone (endoscopic or percutaneous) failed in all patients and open redo-surgery was deemed potentially harmful. Bilomas were externally drained in all patients before Onyx application. For the closure of bile leaks, Onyx was injected through a microcatheter in a previously built coil nest to keep Onyx in place. All bile leaks were initially closed immediately. In the 2nd week after Onyx embolization, 2 patients showed recurrent small bile leaks without clinical symptoms. In the 4th week after Onyx application, all leaks were closed. No complications occurred.

Conclusion: All leaking bile ducts were initially closed immediately after Onyx application. In the 2nd week after Onyx application, 2 patients showed small bile leaks without clinical symptoms. All leaks were closed in the 4 th week after 
Schlussfolgerung: Nach Onyxapplikation waren alle Galleleckagen sofort verschlossen. In der 2 . Woche nach Onyx zeigten $2 \mathrm{~Pa}-$ tienten ein kleines asymptomatisches Leck, welches in der 4. Woche nach Onyxapplikation komplett verschlossen war. Kernaussagen: Die perkutane Behandlung postoperativer Galleleckagen mit Onyx scheint eine effektive Therapie zu sein, wenn eine endoskopische Therapie scheitert und erneute operative Revisionen zu invasiv sind.
Onyx application. Key Points: Percutaneous treatment of postoperative bile leaks with Onyx seems to be an effective therapy if endoscopy fails and redo-surgery is deemed harmful.

Citation Format:

- Uller W, Müller-Wille R, Loss M etal. Percutaneous Management of Postoperative Bile Leaks with an Ethylene Vinyl Alcohol Copolymer (Onyx). Fortschr Röntgenstr 2013; 185: 1182 1187

\section{Introduction}

Bile leaks represent a common complication of liver surgery and predispose to the development of biliary peritonitis, sepsis and other complications [1]. Adequate treatment of iatrogenic bile leaks remains challenging. Endoscopic management is often recommended as the initial treatment of iatrogenic bile duct injuries [2, 3]. Nevertheless, endoscopy is rarely feasible after hepaticojejunostomy with Roux-en-Y reconstruction and endoscopy fails if biliary leaks arise from the cut surface of the liver. Percutaneous management is an alternative treatment approach if endoscopy fails and bile leaks cannot be treated surgically. Usually, the management consists of external drainage by percutaneous transhepatic biliary drainage (PTBD), but in some cases bile leaks persist even after PTBD.

Percutaneous embolization of the bile leak with permanent liquid agents is limited due to poor controllability during application in the absence of blood flow (e.g. Histoacryl) or may cause irreparable damage to the bile system (e.g. ethanol). Onyx (ev3, Irvine, USA) is a liquid embolic agent for transcatheter embolization of vascular structures consisting of an ethylene vinyl alcohol copolymer dissolved in various concentrations of dimethyl sulfoxide (DMSO) and opacified with micronized tantalum powder. Accordingly, Onyx provides good contrast for visualization under fluoroscopy. So far, Onyx has been used for embolization of vascular processes $[4,5]$. Although there are some anecdotal reports about ethanol ablation for segmental bile duct leakage [6], to the best of our knowledge, interventional percutaneous closure of bile ducts with Onyx in case of bile leak has not yet been described.
We present our initial technical and clinical experience with five patients who suffered from persistent postoperative bile leaks and who were successfully treated with Onyx application.

\section{Patients and Methods \\ $\nabla$}

\section{Patient Cohort}

From January to September 2012, 5 patients (2 women, 3 men; age range $51-75$ years) with bile leaks after surgery were referred to our department. The type of surgery, site of bile leak and time interval between surgery and Onyx application are summarized in $\bullet$ Table 1.

\section{Interventional Procedures}

For the procedure, explicit and special informed consent was given in three cases. Two patients were mechanically ventilated and anesthetized during the periinterventional period. Therefore, their relatives gave consent. The PTBD procedure and the Onyx applications were performed during general anesthesia in every patient in order to permit adequate periods of apnea and prevent artifacts due to movement or breathing. Control cholangiographies were performed under local anesthesia and intravenous sedation.

Percutaneous transhepatic cholangiography (PTC) was performed using a CHIBA needle (21 G, Boston Scientific, Natick, MA, USA) and advanced under fluoroscopic guidance into a peripheral bile duct. The biliary tree was catheterized using the Accustick Introducer System (Boston Scientific) over a 0.018inch Cope wire (Cook, Bjaeverskov, Denmark). Cholangiography

Table 1 Age and sex, indications for surgery, surgical procedures, site of bile leak and time between surgery and Onyx application ${ }^{1}$.

Tab. 1 Alter und Geschlecht der Patienten, Indikation und Beschreibung der Operationen, Lokalisation der Galleleckage und Zeitspanne zwischen Operation und Onyxapplikation' ${ }^{1}$.

\begin{tabular}{|c|c|c|c|c|c|c|}
\hline patient \# & $\begin{array}{l}\text { age } \\
\text { (years)/sex }\end{array}$ & indication for surgery & surgical procedure & $\begin{array}{l}\text { interval between } \\
\text { surgery and Onyx } \\
\text { application }\end{array}$ & $\begin{array}{l}\text { drainage catheter of } \\
\text { biloma (before Onyx } \\
\text { application) }\end{array}$ & site of bile leak \\
\hline 1 & $56 / m$ & necrotizing pancreatitis & cholecystectomy, necrosectomy & $13 d$ & CT-guided & cystic duct stump \\
\hline 2 & $75 / f$ & GIST & $\begin{array}{l}\text { resection S V - VIII, part of S IVa } \\
\text { and III } \\
\text { (reconstruction V. portae/ } \\
\text { V. hepatica) }\end{array}$ & $20 d$ & CT-guided & $\begin{array}{l}\text { cut surface of the } \\
\text { liver }\end{array}$ \\
\hline 3 & $51 / f$ & $\begin{array}{l}\text { cholangiocellular carci- } \\
\text { noma }\end{array}$ & $\begin{array}{l}\text { resection S VII and VIII, periton- } \\
\text { ectomy, diaphragmatic resection } \\
\text { (reconstruction ICV) }\end{array}$ & $111 d$ & surgical & $\begin{array}{l}\text { cut surface of the } \\
\text { liver }\end{array}$ \\
\hline 4 & $60 / f$ & cholecystitis & cholecystectomy & $35 d$ & surgical & cystic duct stump \\
\hline 5 & $62 / \mathrm{m}$ & $\begin{array}{l}\text { cholangiocellular carci- } \\
\text { noma }\end{array}$ & $\begin{array}{l}\text { exploration, removal of an intra- } \\
\text { peritoneal port system }\end{array}$ & $26 d$ & CT-guided & surface of the liver \\
\hline
\end{tabular}

${ }^{1} \mathrm{f}$ : female, $\mathrm{m}$ : male, GIST: gastrointestinal stroma tumor, S: liver segment, $d$ : days, ICV: inferior cava vein.

f: weilblich, m: männlich, GIST: Gastrointestinaler Stromatumor, S: Lebersegment, d: Tage, ICV: inferiore Vena cava. 
was performed and via the Accustick sheath, a glide guide wire (0.035-inch Terumo, Leuven, Belgium) and an angled catheter (modified RIM 4F, Cook) were introduced and placed close to the bile leak. The RIM catheters were shortened by cutting the original angle to an angle adapted to the biliary system. Before Onyx application through microcatheters (Progreat, Terumo; Apollo, ev3) coils (Azur, Terumo: patient \#3 and \#4 or Interlock, Boston Scientific: patient \#1 and \#2) were placed inside the leaking bile duct or the cystic stump close to the bile leak to create a basket to mechanically prevent non-polymerized Onyx from dislocation. We used Onyx 34, a solution of DMSO with the highest concentration of the ethylene vinyl alcohol copolymer (EVOH). Onyx 34 is more viscous compared to solutions consisting of lower EVOH concentrations (e.g. Onyx 18).

After Onyx application, the macrocatheters were very slowly flushed with $40 \mathrm{ml}$ of $\mathrm{NaCl}$ to facilitate dissolution of the DMSO from the Onyx cast to accelerate polymerization in the absence of blood flow. Afterwards, $8.5 \mathrm{~F}$ internal-external biliary drainage catheters (Mac-Loc Locking Loop, Cook) were placed. Control PTC was performed using a sheath immediately after the procedure and in the $2^{\text {nd }}$ and $4^{\text {th }}$ week after Onyx application. Control PTC was necessary in all patients to rule out early distinct recurrence of the leak, which would have consequently necessitated further therapy (e.g. surgical revisions) in these seriously ill patients.

\section{Results \\ $\nabla$}

Two patients suffered from cystic duct stump insufficiency after cholecystectomy during surgical necrosectomy of necrotic pancreatitis and after cholecystectomy for acute cholecystitis (patients \#1 and \#4; $\odot$ Table 1). In patient \#4, preexisting Crohn's disease lead to surgical revisions for small bowel lesions after cholecystectomy. Patients \#2 and \#3 suffered from bile leaks at the cut surface of the liver after extended liver resection. Patient \#5 presented with bile leak at the surface of segment VI due to a perihepatic abscess after abdominal exploration and surgical removal of an intraperitoneal port system. Endoscopy was the first treatment approach but failed in all patients due to deformity of the duodenum (in case of necrotic pancreatitis and preexisting Crohn's disease) and due to the location of the bile leak at the surface of the liver. Hence, percutaneous management was carried out.

Fluid drains for bilomas were placed in all patients before Onyx treatment. Computed tomography (CT)-guided percutaneous drainage was performed in patients \#1, \#2 and \#5. Surgical drains were still in place in patients \#3 and \#4 prior to Onyx application. Fluoroscopic control showed a connection between the biloma and the biliary system in all patients confirming the bile leak. PTBD before Onyx application was performed in 3 patients without any treatment effect on the bile leak. The duration of the PTBD procedure prior to Onyx application ranged from 6 days to 63 days. Table 1 shows patient age, the indication for surgery, the preceding operation, the site of bile leakage and the interval between surgery and Onyx application.

PTC showed non-dilated intrahepatic bile ducts in all patients except patient \#5. Coil placement was performed in all cases except in patient \#5. In this patient, the diameter of the bile duct that lead to the biliary leak was deemed too small to perform and necessitate additional coil application. The very small size of the leaking bile duct was expected to sufficiently keep Onyx in place without further mechanical help ( $\bullet$ Fig. 1). In the other cases, the contrast medium flow through the leaks was slowed down after coil application, but the bile leak persisted in all cases ( $\bullet$ Fig. 2 ). The flow was slower after the application of hydrogel coils (patients \#3 and \#4) than after the application of fibered coils (patients \#1 and \#2).

After successful placement of $1-2.5 \mathrm{ml}$ of Onyx (34) in the coil basket with an allowed proximal and distal extension of 1 $3 \mathrm{~cm}$, PTC detected no persisting bile leakage immediately after embolization in all patients. Between Onyx application and saline flush, no Onyx movement was detected under fluoroscopy. 8.5 F internal-external drains were placed in the biliary system of all but patient \#1.

Control PTC in the $2^{\text {nd }}$ week after Onyx application showed a recurrent small leak in patient \#2 who remained clinically asymptomatic and a recurrent moderate leak in patient \#1 after strong contrast application through sheaths. Patient \#1 has not undergone PTBD after Onyx application and suffered from recurrent moderate leakage. The PTBD (8.5 F internal-external drainage catheter) procedure was performed in this patient after the detection of a recurrent bile leak. Due to the recurrent leaks in the first two patients, we preferred hydrogel coil placements in the following patients in order to further slow bile flow before Onyx application. Four weeks post Onyx application, none of the patients showed any bile leakages. No complications due to interventional management of the bile leaks occurred.

\section{Discussion \\ $\nabla$}

The incidence of postoperative bile leakage differs widely and depends on the type of surgery. Bile leakage occurs in 0.1 to $1.4 \%$ of patients after cholecystectomy but is more common after extended hepatectomy $[7,8]$. Recently, a bile leak rate of $28 \%$ has been reported after extended right hepatectomy, preceded by right portal vein ligation and in situ liver parenchyma splitting to achieve increased left liver hypertrophy [9]. Zimmitti et al. reported an increasing incidence of postoperative bile leaks associated with aggressive operative strategies like extended right hepatectomy, repeat hepatectomy and en bloc diaphragmatic resection [10]. In this study, the complexity of liver surgery and the progressive expansion of indications for liver surgery lead to a concomitant increase in bile leak rate. Nevertheless, biliary leakage may cause intraperitoneal septic complications and carry high risks of liver failure and operative mortality [8, 11]. The management of bile leaks has changed from repeat laparotomies to mainly non-surgical interventions in the last years. Immediate drainage or biliary decompression is required to prevent intraperitoneal collections and sepsis [11]. While some small intrahepatic bile duct leaks are often self-limiting and respond to external drainage, major leaks require further treatment [12]. Endoscopic management resulted in bile leak healing in $82 \%$ of the cases [13]. However, endoscopy fails under certain conditions such as ongoing severe acute necrotizing pancreatitis with deformity of the duodenum, hepaticojejunostomy and Roux-en-Y reconstruction or bile leaks at the cut surface of the liver. In these situations, PTBD represents the approach of choice and provides a considerable reduction in repeated laparotomies. Recently, less invasive methods, such as PTBD combined with percutaneous drainage of bilomas, were successfully performed [14, 15].

Surgical treatment is required when conservative endoscopic and radiological management fails and can be performed by liver resection, bile duct reconstruction or bilioenteric anastomosis $[16,17]$. On the one hand, surgical re-exploration is often compli- 

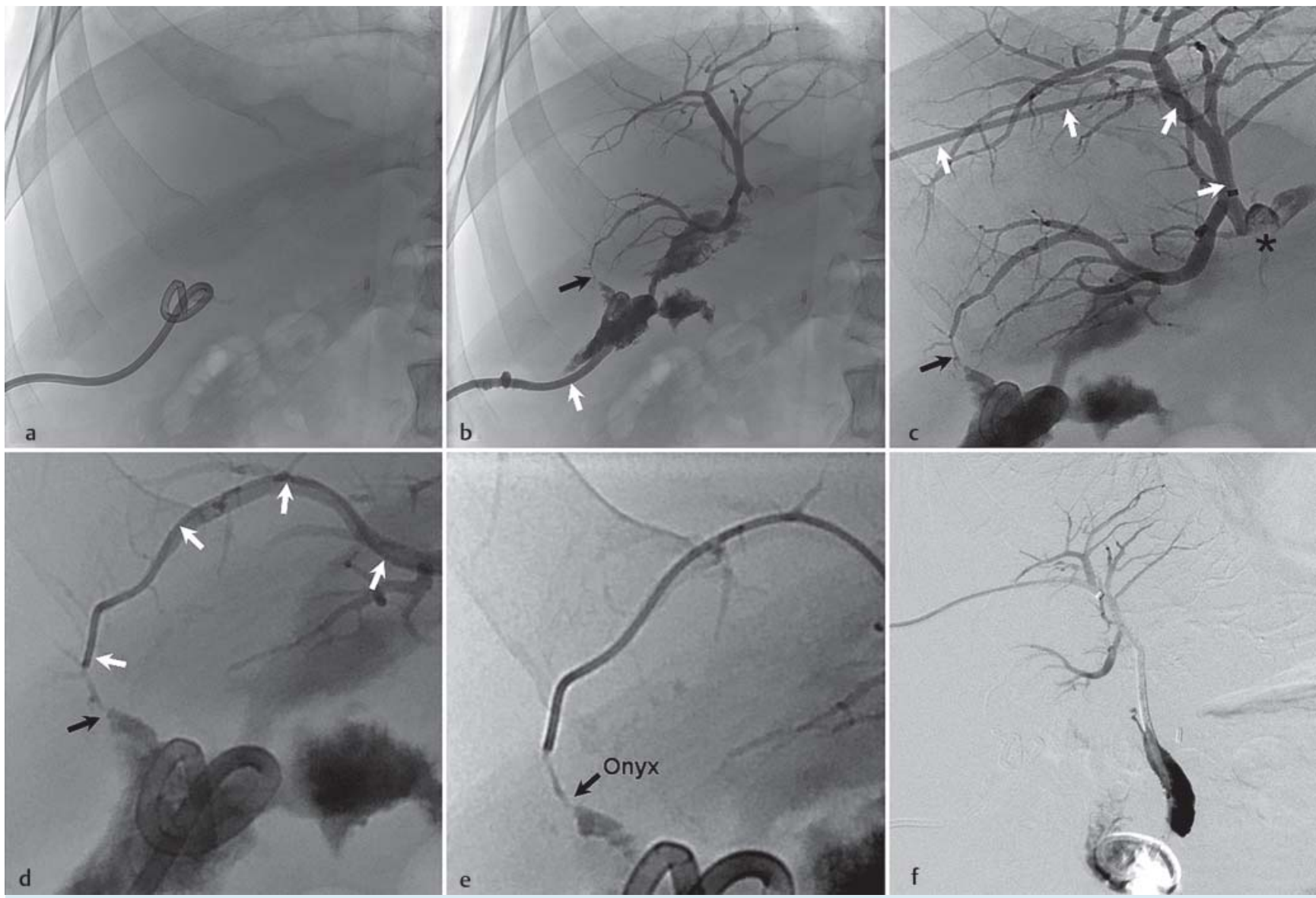

Fig. 1 This 62-year-old man presented with a perihepatic abscess prior to bile leak after abdominal exploration and removal of an intraperitoneal port system due to cholangiocellular carcinoma (patient \#5). a Fluoroscopy shows the drain (CT-guided 12-F locking-loop), which was placed in the abscess. b After contrast medium application through the drain (white arrow), contrast medium spreads in the biliary system due to a bile leakage at the liver surface of segment VI (black arrow). c The Accustick Introducer System (white arrows) is placed in the biliary system and percutaneous transhepatic cholangiogram (PTC) detects the bile leak once again (black arrow). Furthermore, the malignant stenosis is depicted (asterisk). d The leaking bile duct (black arrow) is catheterized with a microcatheter (white arrows). e Opacified Onyx (black arrow) is visible in the leaking bile duct; the diameter of this bile duct was deemed too small to perform and necessitate additional coil application. $\mathbf{f}$ Control PTC in the 2nd week after Onyx application shows complete closure of the leaking bile duct.

Abb. 1 Dieser 62-jährige Patient entwickelte einen perihepatischen Abszess nach abdomineller Exploration und Entfernung eines intraperitonealen Portsystems wegen eines Hepatozellulären Karzinoms (Patient \#5). a Die Fluoroskopie zeigt die im Abszess platzierte Drainage (12-F locking-loop). b Nach Kontrastmittelapplikation über die Abszessdrainage (weißer Pfeil) kommt es zu einer Kontrastmittelverteilung in den Gallengängen auf Grund eines Gallelecks an der Leberoberfläche des Segments VI (schwarzer Pfeil). c Nach Platzierung des Accustick Introducer Systems (weiße Pfeile) im Gallengangssystem und Durchführung einer perkutanen Cholangiografie (PTC) erneut Nachweis der Leckage (schwarzer Pfeil). Darüberhinaus zeigt sich die maligne Stenose (Stern). d Der betreffende Gallengang (schwarzer Pfeil) wird mit einem Mikrokatheter sondiert (weiße Pfeile). e Das röntgendichte Onyx (schwarzer Pfeil) ist nach Applikation im betreffenden Gallengang sichtbar. Auf Grund des geringen Durchmessers des Gallengangs war eine vorherige Coilapplikation weder nötig noch möglich. $\mathbf{f}$ Die Kontroll-PTC in der 2. Woche nach Onyxembolisation zeigt das Galleleck noch immer verschlossen.

cated due to the presence of adhesions [1]. On the other hand, successful percutaneous management of bile leaks requires long therapy courses. An average duration of PTBD treatment of 6 weeks to 80 days has been reported $[14,18]$.

As seen in our series, Onyx application for the management of bile leaks can shorten therapy courses substantially when combined with PTBD.

Onyx consists of an ethylene vinyl alcohol copolymer (EVOH) dissolved in various concentrations of dimethyl sulfoxide (DMSO). Opacified with micronized tantalum powder, Onyx is perfectly visible under fluoroscopy. The viscosity of the mixture is determined by the concentration of $\mathrm{EVOH}$. Solutions with a higher concentration of EVOH are more viscous. When the mixture comes in contact with aqueous solutions, DMSO diffuses away and EVOH precipitates. This precipitation starts at the interface while the core is still liquid. As biliary flow is substantially slower than blood flow, DMSO diffusion may be slower and EVOH remains liquid for a longer time [19]. For circumvention of this problem, we used high concentrations of EVOH $(8 \%$ EVOH; Onyx 34) as well as coils in order to prevent initial dislocation of non-polymerized Onyx. The coil basket inhibited early dislocation of Onyx during application (when it is more liquid and precipitation has not completed) effectively. Additionally, we slowly rinsed the biliary leak site after Onyx application with saline to accelerate the polymerization via DMSO diffusion without detection of Onyx displacement. On the other hand, due to the slow precipitation of $\mathrm{EVOH}$, in contrast to the vascular system there is no risk of "gluing" the microcatheter into the 


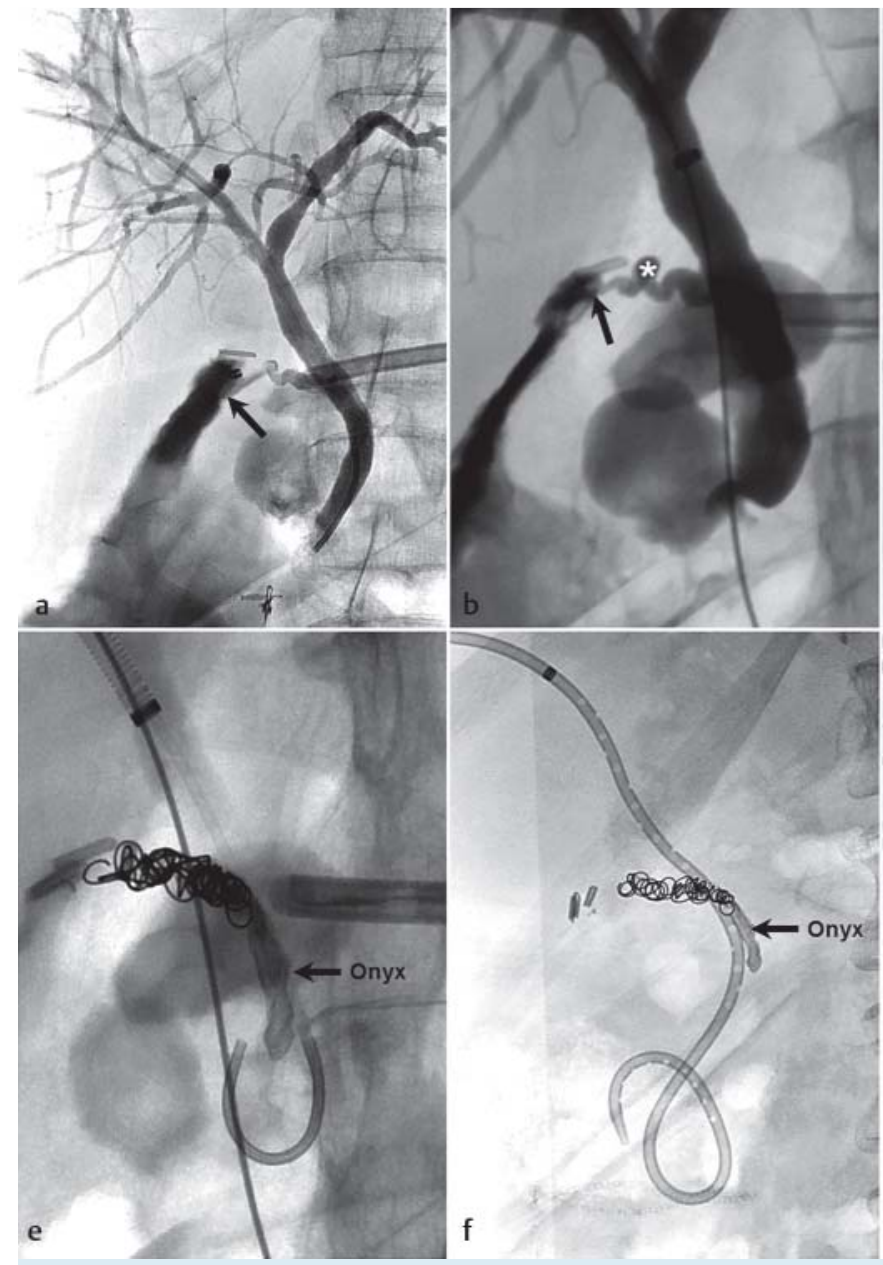

Fig. 2 Cystic stump leakage in a 60-year-old woman after cholecystectomy and surgical revisions due to preexisting Crohn's disease: a Percutaneous transhepatic cholangiogram (PTC) detects the leakage (black arrow) of the cystic duct stump. $\mathbf{b}$ Enlarged illustration shows the leakage (black arrow) of the cystic stump (asterisk) once again. $\mathbf{c}$ A modified RIM catheter and a Progreat microcatheter are placed close to the bile leak and coils are placed inside the leaking cystic duct stump close to the bile leak. $\mathbf{d}$ After coil application, the bile leak is still visible (black arrow). e The coil basket prevents Onyx from dislocation. $\mathbf{f}$ Fluoroscopy shows the placement of a $8.5 \mathrm{~F}$ internal-external drain and the Onyx cast located in the cystic duct. g PTC proves closure of the bile leak immediately after Onyx application. h PTC detects no recurrent bile leak in the 2 nd week after Onyx application.

biliary system as compared to Histoacryl. Small amounts of Onyx may dislocate in the proximal bile ducts during application, but in our patients, these possible plugs remained without symptoms or complications. This may be due to the fact that the biliary system gets wider with the flow of bile, thus any potential dislocation of Onyx would not occlude the biliary system but pass through it until it is expelled to the small intestine. In the control fluoroscopies, we observed no change concerning the overall volume and the shape of the Onyx cast (computerized volumetric analysis was not performed). This suggests that Onyx was not fragmented or dislocated during the observation time. Furthermore, DMSO did not lead to any signs of cholangitis or infection. There were no signs of irreparable damage to the biliary tree as possible in ethanol ablation.

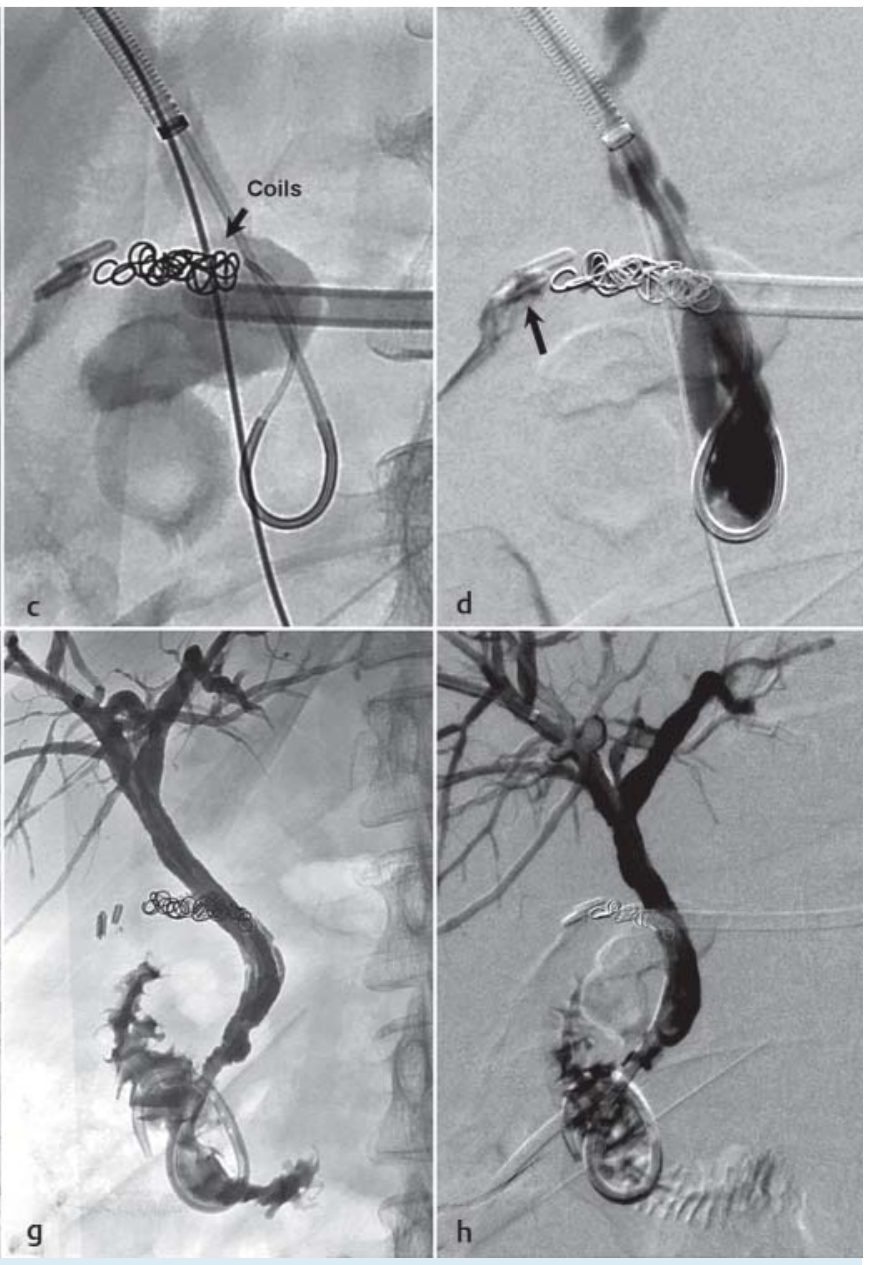

Abb. 2 Insuffizienz des Duktus zystikus bei einer 60-jährigen Patientin nach Cholezystektomie und chirurgischen Revisionen wegen vorbestehendem M. Crohn (Patient \#4): a Die perkutane Cholangiografie (PTC) zeigt die Insuffizienz des Duktus zystikus (schwarzer Pfeil). b Die vergrößerte Darstellung zeigt erneut die Insuffizienz (schwarzer Pfeil) des Duktus zystikus (Stern). c Ein modifizierter RIM-Katheter und ein Progreat-Mikrokatheter sind zur Coilapplikation unmittelbar proximal der Leckage im Duktus zystikus platziert. d Nach Coilapplikation ist die Leckage noch nachweisbar (schwarzer Pfeil). e Das Coilpaket verhindert eine Dislokation des Onyx. f Darstellung der eingebrachten 8.5-F Intern-extern Drainage sowie des sich im Duktus zystikus befindlichen Onyx. g Die PTC beweist den Verschluss der Leckage unmittelbar nach Onyxapplikation. h Kein Nachweis eines wiederauftretenden Gallelecks in der 2. Woche nach Onyxapplikation.

\section{Conclusion}

Management of bile leaks with Onyx is technically feasible if special considerations are taken into account. First results demonstrate that this procedure is effective especially if the bile leak rises from small ducts of the liver surface or if endoscopy fails and redo-surgery is deemed harmful.

\section{"Clinical Relevance of the Study"}

\section{Management of bile leaks with Onyx}

- Is technically feasible

- Is an alternative therapy if bile drainage alone (percutaneous or endoscopic) fails and redo-surgery is deemed harmful

- Is effective if the bile leak rises from the liver surface as well as from the cystic stump 


\section{References}

1 Pace RF, Blenkharn JI, Edwards WJ et al. Intra-abdominal sepsis after hepatic resection. Ann Surg 1989; 209: $302-306$

2 Davids PH, Tanka AK, Rauws EA et al. Benign biliary strictures. Surgery or endoscopy? Ann Surg 1993; 217: 237-243

3 Tocchi A, Mazzoni G, Liotta G et al. Management of benign biliary strictures: biliary enteric anastomosis vs endoscopic stenting. Arch Surg 2000; 135: $153-157$

4 Adamus R, Uder M, Kleinschmidt T et al. Embolization of acute abdominal and thoracic hemorrhages with ethylene vinyl alcohol copolymer (Onyx): initial experiences with arteries of the body trunk. Fortschr Röntgenstr 2010; 182: 900-904

5 Eberhardt KM, Treitl M, Sadeghi-Azandaryani M. An endovascular technique for treatment of high-risk iatrogenic aortic pseudoaneurysms with the ethylene vinyl alcohol copolymer onyx and aortic stent grafting. Fortschr Röntgenstr 2012; 184: 1163 -1165

6 Kyokane T, Nagino M, Oda $\mathrm{K}$ et al. An experimental study of selective intrahepatic biliary ablation with ethanol. J Surg Res 2001; 96: 188 196

7 Karvonen J, Gullichsen R, Laine S et al. Bile duct injuries during laparoscopic cholecystectomy: primary and long-term results from a single institution. Surg Endosc 2007; 21: 1069-1073

8 Lo CM, Fan ST, Liu CL et al. Biliary complications after hepatic resection: risk factors, management, and outcome. Arch Surg 1998; 133: 156 161

9 Schnitzbauer AA, Lang SA, Goessmann H et al. Right portal vein ligation combined with in situ splitting induces rapid left lateral liver lobe hypertrophy enabling 2-staged extended right hepatic resection in small-for-size settings. Ann Surg 2012; 255: 405-414

10 Zimmitti G, Roses RE, Andreou A et al. Greater complexity of liver surgery is not associated with an increased incidence of liver-related complications except for bile leak: an experience with 2,628 consecutive resections. J Gastrointest Surg 2013; 17: 57-64; discussion p 6455

11 Yamashita Y, Hamatsu T, Rikimaru T et al. Bile leakage after hepatic resection. Ann Surg 2001; 233: $45-50$

12 Kapoor S, Nundy S. Bile duct leaks from the intrahepatic biliary tree: a review of its etiology, incidence, and management. HPB Surg 2012: 752932

13 Binmoeller KF, Katon RM, Shneidman R. Endoscopic management of postoperative biliary leaks: review of 77 cases and report of two cases with biloma formation. Am J Gastroenterol 1991; 86: 227-231

14 Stampfl $U$, Hackert T, Radeleff $B$ et al. Percutaneous management of postoperative bile leaks after upper gastrointestinal surgery. Cardiovasc Intervent Radiol 2011; 34: 808-815

15 Quintana Osuna GT, Krug KB, Lackner K. Treatment of biliary leakage by an adjoined antegrade and retrograde percutaneous transhepatic cholangio drainage approach: a case report. Fortschr Röntgenstr 2011; 183: 74-76

16 Belghiti J, Hiramatsu K, Benoist S et al. Seven hundred forty-seven hepatectomies in the 1990s: an update to evaluate the actual risk of liver resection. J Am Coll Surg 2000; 191: 38-46

17 Czerniak A, Thompson JN, Soreide 0 et al. The management of fistulas of the biliary tract after injury to the bile duct during cholecystectomy. Surg Gynecol Obstet 1988; 167: 33 -38

18 Civelli EM, Meroni R, Cozzi G et al. The role of interventional radiology in biliary complications after orthotopic liver transplantation: a singlecenter experience. Eur Radiol 2004; 14: 579-582

19 Wohlgemuth WA, Uller W, Müller-Wille R. Liquid embolic agents-Onyx as probem solver. Radiologe 2013; 53: 223-239 